九州大学学術情報リポジトリ

Kyushu University Institutional Repository

\title{
Clay Mineralogy and Vertical Distribution of Cadmium in a Soil Profile in a Reclaimed Paddy Field in Kyushu, Japan
}

Huy, Trinh Quang

Laboratory of Soil Science, Division of Soil Science and Plant Production, Dpartment of Plant Resoruces, Graduate School of Bioresource and Bioenvironmental Sciences, Kyushu University

Mori, Yuki

Laboratory of Soil Science, Division of Soil Science and Plant Production, Dpartment of Plant Resoruces, Graduate School of Bioresource and Bioenvironmental Sciences, Kyushu University

Sumikura, Mitsuhiro

Laboratory of Soil Science, Division of Soil Science and Plant Production, Dpartment of Plant Resoruces, Graduate School of Bioresource and Bioenvironmental Sciences, Kyushu University

Wada, Shin-Ichiro

https://doi.org/10.5109/4515

出版情報：九州大学大学院農学研究院紀要. 47 (2)，pp.447-452，2003-02-01. Faculty of Agriculture, Kyushu University

バージョン：

権利関係: 


\title{
Clay Mineralogy and Vertical Distribution of Cadmium in a Soil Profile in a Reclaimed Paddy Field in Kyushu, Japan
}

\author{
Trinh Quang HUY*, Yuki MORI*, Mitsuhiro SUMIKURA* \\ and Shin-Ichiro WADA ${ }^{\dagger}$
}

\author{
Laboratory of Soil Science, Division of Soil Science and Plant Production, Department of \\ Plant Resources, Faculty of Agriculture, Kyushu University, \\ Fukuoka 812-8581, Japan \\ (Received October 30, 2002 and accepted November 7, 2002)
}

\begin{abstract}
We collected six soil samples from a soil profile in a reclaimed paddy field in Omuta, Kyushu, Japan and analyzed for basic chemical properties, clay mineralogy and total cadmium content. The all six soil samples resembled with regard to exchangeable cation composition and clay mineralogy. The total cadmium content on the whole soil basis was 5.1 and $3.5 \mathrm{mg} \mathrm{kg}^{-1}$ for $0-15 \mathrm{~cm}$ and $15-35 \mathrm{~cm}$ layers, respectively, and it was in a relatively narrow range from 1.2 to 1.8 for the underlying layers. The cadmium content on the clay basis was also highest for the surface soil with a value of $19 \mathrm{mg} \mathrm{kg}^{-1}$ and those for the underlying layers were fairly high with values from 9 to $12 \mathrm{mg} \mathrm{kg}^{-1}$. According to physical chemistry of adsorption, the equilibrium concentration depends primarily on the adsorption per unit amount of adsorbent, the clay content as well as total cadmium content should be determined for assessing bioavailability of cadmium and remediation planning.
\end{abstract}

\section{INTRODUCTION}

Excessive dietary intake of cadmium causes kidney troubles that induce the violation of calcium metabolism and finally develop osteomalacia (Asami, 1991). The itai-itai disease that broke out in the Jinzu River basin in central Japan in 1920s and on is one of the well-known examples of the cadmium-toxicosis (Asami, 2001). The nationwide soil survey revealed that approximately 7000 ha of the agricultural land was polluted with cadmium to give cadmium concentration of $>1 \mathrm{mg} \mathrm{kg}^{-1}$ to the rice grown therein (Kawamura, 1996). Of 7000 ha, about 100 ha of polluted land was found in Omuta area, Kyushu (Yoshiike, 1979), where the pollution was brought about mostly by the fallout of cadmium-containing particulates that were discharged from chimneystacks of a near by smelting works.

In this area as well as in other part of the country, the major countermeasure has been soil dressing, i. e. covering polluted soil with fresh soil. It has been practiced for most part of the polluted field but some still remains untreated. Since the root system of rice plant develops mostly in 10 to $15 \mathrm{~cm}$, the $25 \mathrm{~cm}$ soil dressing has been proven to be quite effective for suppressing cadmium uptake by rice unless there was no disturbance of soil.

\footnotetext{
* Laboratory of Soil Science, Division of Soil Science and Plant Production, Department of Plant Resources, Graduate School of Bioresource and Bioenvironmental Sciences, Kyushu University, Fukuoka 812-8581, Japan

† Corresponding author (E-mail: wadasi@agr.kyushu-u.ac.jp)
} 
However, as a result of the overproduction of rice in these three decades, farmers are obliged to grow upland crops and the trend has been accelerated from late 1990s. In the upland crop production, the disturbance of soil layers is almost inevitable because of the need for construction of mole drain system and deep plowing in addition to deep-rooting nature of upland crops. In this situation, some remediation technologies other than soil dressing are urgently needed and, for assessing feasibility of the possible methods, the information about the content and its chemical form is indispensable. In the past national soil pollution survey program, the cadmium content of surface soil in suspicious areas was determined but the distribution of cadmium in soil profile has not received due attention.

\section{MATERIALS AND METHODS}

Soil samples were obtained in December, 2001 from a paddy field in Showabiraki, Omuta-shi where the paddy field was reclaimed from the sea sediments in a period from 1953 to 1967 . The reclaimed field lies at about $1.2 \mathrm{~km}$ west to the metal smelting plant. The surface soil was taken with a scoop and the subsoil samples were drawn by a hand auger from every $20 \mathrm{~cm}$ layer down to $115 \mathrm{~cm}$ deep. The collected soil samples were air-dried and passed through $2-\mathrm{mm}$ screen.

Basic properties of the soil samples were determined following Wada and Umegaki (2001). Particle size distribution and clay mineralogy were determined with the method described by Hai et al. (2002). Total cadmium was analyzed basically with the method developed by Asami and Kato (1977) after a preliminary digestion of the soil samples with $7 \%$ hydrogen peroxide to remove humic substance. All the analyses except for X-ray diffraction were carried out in duplicate and the results were averaged.

\section{RESULTS AND DISCUSSION}

The analytical results were summarized in Table 1. The soils in the profile are light to medium textured with clay content ranging from 126 to $275 \mathrm{~g} \mathrm{~kg}^{-1}$. In terms of texture, the soils from the $0-15 \mathrm{~cm}$ and $15-35 \mathrm{~cm}$ horizons are quite similar and the underlying layers are almost uniform except for a significantly higher gravel content and lower sand

Tàble 1. Chemical properties of soil samples

\begin{tabular}{|c|c|c|c|c|c|c|c|c|c|c|c|}
\hline \multirow{2}{*}{ Depth } & \multirow{2}{*}{$\mathrm{pH}$} & \multirow{2}{*}{$\mathrm{OC}^{*}$} & \multicolumn{4}{|c|}{ Exchangeable cations } & \multicolumn{4}{|c|}{ Particle size distribution } & \multirow[t]{2}{*}{$\mathrm{Cd}^{* *}$} \\
\hline & & & $\mathrm{Ca}$ & $\mathrm{Mg}$ & $\mathrm{K}$ & $\mathrm{Na}$ & Gravel & Sand & Silt & Clay & \\
\hline $\mathrm{cm}$ & & $\mathrm{g} \mathrm{kg}^{-1}$ & \multicolumn{4}{|c|}{$\mathrm{cmol}_{\mathrm{c}} \mathrm{kg}^{-\mathrm{i}}$} & \multicolumn{4}{|c|}{$\mathrm{g} \mathrm{kg}^{-1}$} & $\mathrm{mg} \mathrm{kg}^{-1}$ \\
\hline $0-15$ & 5.8 & 25.6 & 14.1 & 4.35 & 1.56 & 2.15 & 98 & $309^{\circ}$ & 318 & 275 & 5.10 \\
\hline $15-35$ & 7.3 & 12.1 & 26.8 & 5.09 & 1.76 & 3.71 & 127 & 380 & 207 & 286 & 3.52 \\
\hline $35-55$ & 6.7 & 3.2 & 42.5 & 4.51 & 1.40 & 3.19 & 206 & 541 & 118 & 135 & 1.78 \\
\hline $55-75$ & 7.9 & 3.8 & 38.0 & 5.40 & 1.70 & 4.38 & 389 & 373 & 101 & 137 & 1.22 \\
\hline $75-95$ & 7.9 & 5.0 & 37.4 & 5.61 & 1.94 & 5.38 & 163 & 557 & 131 & 149 & 1.63 \\
\hline $95-115$ & 8.0 & 4.2 & 31.1 & 6.18 & 2.46 & 6.87 & 199 & 579 & 96 & 126 & $1: 17$ \\
\hline
\end{tabular}

*; Organic carbon

**; Total cadmium content 
content in $55-75 \mathrm{~cm}$ layer. Since the sporadic intervention of layers with significantly different texture is common in reclaimed land, it is not justified to generalize the present result. But it is highly probable that the texture is quite uniform at least through the topsoil $(0-35 \mathrm{~cm})$ and also through the subsoil $(35-115 \mathrm{~cm})$.

The ammonium acetate extractable cation composition and $\mathrm{pH}$, particularly the high magnesium and sodium content and as well as the high $\mathrm{pH}$ suggest that the influence of seawater still remains in lower part of this profile. A part of the extractable calcium would be due to the dissolution of calcareous shells and the sum of the ammonium acetate extractable cations may not represent the cation exchange capacity. The $\mathrm{pH}$ values as high as 8 would also be due to the equilibration with the shell that is made up of calcium carbonate. The distribution pattern of organic carbon paralleled the clay content.

Figure 1 shows the compiled $\mathrm{X}$-ray diffractograms for clay separates form six layers. The diffraction patterns from clay samples that were subjected to a same chemical treatment are strikingly similar, indicating that the clay mineral composition is almost identical among six soil samples. The magnesium-saturated and air-dried samples showed 001difftractions at $1.4,1.0$ and $0.72 \mathrm{~nm}$. The $1.4 \mathrm{~nm}$ peak mostly shifted to $1.8 \mathrm{~nm}$ leaving a minor peak at the original position. These features indicate the presence of smectite. However, the peak at $1.4 \mathrm{~mm}$ still remained after potassium-saturation and air-drying.' The $1.0 \mathrm{~nm}$ peak in magnesium-saturated and air-dried sample that persisted after heating at $550^{\circ} \mathrm{C}$ indicates the presence of micaceous minerals. The marked reduction of the intensity of $0.7 \mathrm{~nm}$ peak and the weak peaks at $0.7 \mathrm{~nm}$ as well as at $1.4 \mathrm{~nm}$ after $550^{\circ} \mathrm{C}$ heating indicate the presence of kaolin minerals and small amount of chlorite. These evidence show that the soil samples are mineralogically uniform and contain smectite, illite, kaolin minerals, chlorite and probably some vermiculite, although the persistence of fairly strong $1.4 \mathrm{~nm}$ peak after potassium-saturation and air-drying without clear collapse to $1.2 \mathrm{~nm}$ and marked enhancement of the $1.0 \mathrm{~nm}$ peak is puzzling.

The total cadmium content was the highest in the $0-15 \mathrm{~cm}$ layer followed by the $15-35 \mathrm{~cm}$ layer and the contents of the deeper layers were much less, ranging from 1.17 to $1.78 \mathrm{mg} \mathrm{kg}^{-1}$. The smelting plant in Omuta started to work in 1914 and stopped operation partly in 1982 and finally in 1986. This means that the surface soil had been accepting the fallout containing cadmium compounds at least for 19 years. The result that the surface soil has the highest cadmium content accords with this situation of the reclaimed land.

To give deeper insight to the distribution pattern of cadmium in the profile, the total cadmium content per $\mathrm{kg}$ of whole soil and the total cadmium content per $\mathrm{kg}$ of clay are plotted against depth in Figure 2. The distribution pattern of the total cadmium per $\mathrm{kg}$ of whole soil (Figure 2-a) seems to imply that the deposited cadmium accumulates in the surface soil and it was gradually leached down to the deeper layers and this is the conventional view for the mechanism of heavy metal distribution in soil profiles. However, many heavy metals including cadmium are strongly retained by soil minerals, particularly clay sized layer silicate minerals and oxide minerals (Darmawan and Wada, 2001; Mori and Wada, 2002). Therefore, the cadmium content per kg of adsorbent rather than per $\mathrm{kg}$ of whole soil would give more useful information about the possible mechanism of the metal distribution.

The distribution pattern shown in Figure 2-b is quite different from that in Figure 2-a 

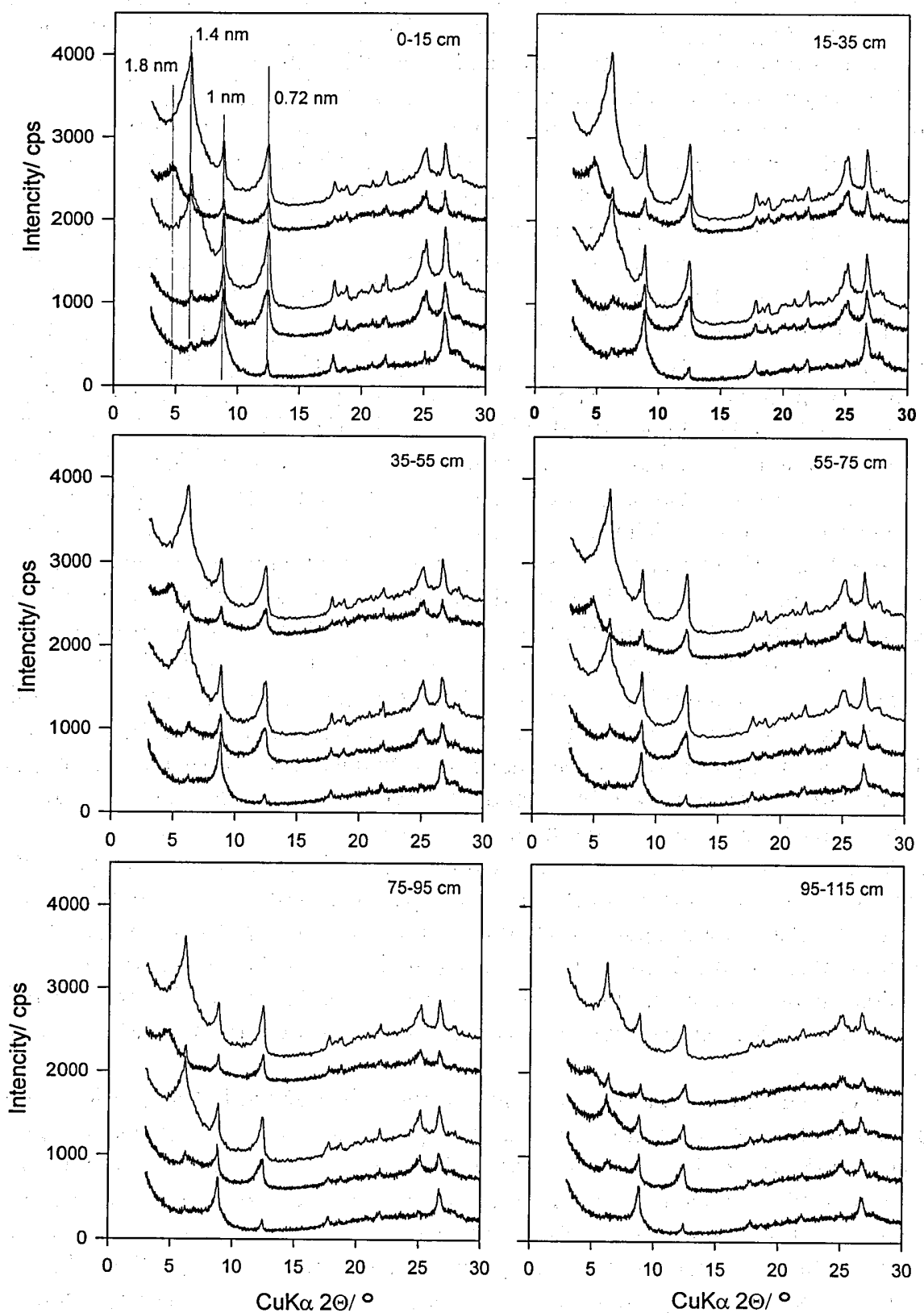

Fig. 1. X-ray diffractograms of clay separates. For each sample, difractrograms are arranged from top to bottom in the order; Mg-saturated and air-dried, Mg-saturated, air-dried and glycerol solvated, $\mathrm{K}$-saturated and air-dried, $\mathrm{K}$-saturated and heated at $300^{\circ} \mathrm{C}$, and $\mathrm{K}$-saturated and heated at $500^{\circ} \mathrm{C}$. 

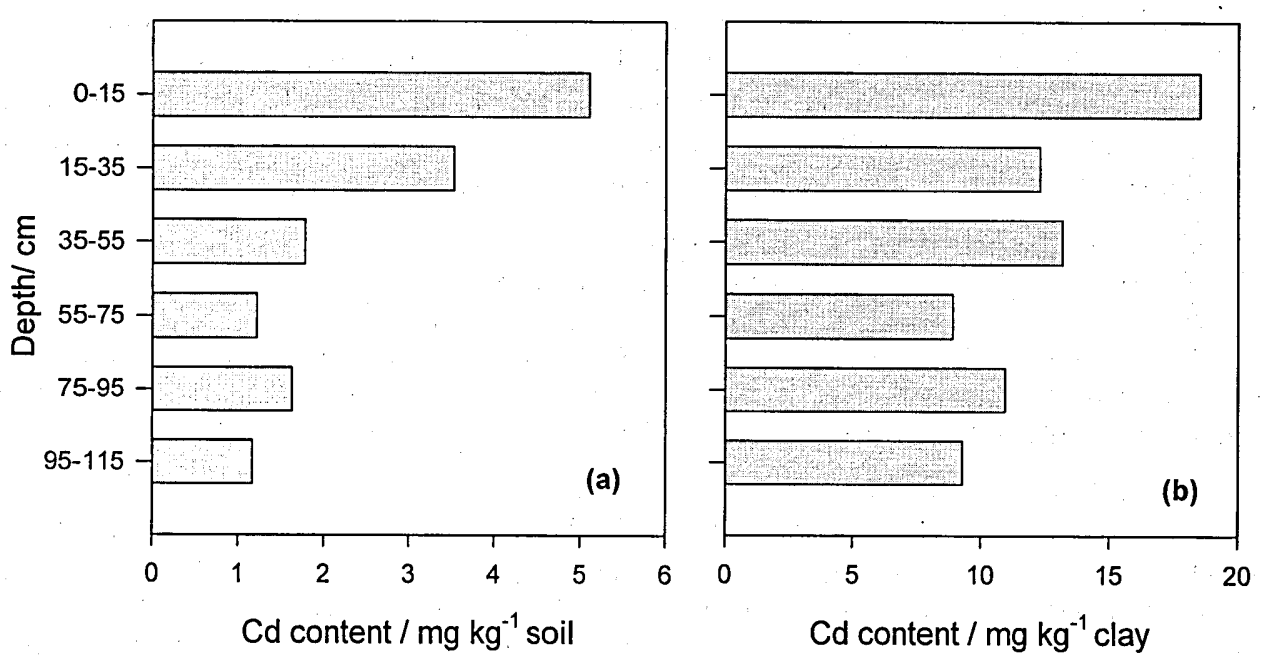

Fig. 2. Total cadmium content on whole soil basis (a), and total cadmium content on clay basis (b).

in that there is no big difference in cadmium content among the six layers. As widely accepted, the adsorption of heavy metal cations can be well approximated by Freundlich or Langmuir adsorption isotherms if the solution $\mathrm{pH}$ is comparable and the adsorption increases with the $\mathrm{pH}$ increases. The cadmium content per $\mathrm{kg}$ of clay, $\mathrm{pH}$ values and the uniformity in the clay mineralogy as evidenced by Figure 1 suggest that the concentration of cadmium in the soil solution would be the highest in the surface layer and those of the underlying layers would be much lower under the present soil condition. However, if the subsoil were brought up to the surface due to some perturbation and the $\mathrm{pH}$ dropped, the adsorbed cadmium would be released into the soil solution.

The bioavailability of soil cadmium to plants is highly correlated with its concentration in the soil solution (Wolt, 1994). The above consideration suggests that plants could uptake the same amount of cadmium from soils with the same cadmium content per $\mathrm{kg}$ of clay even if the cadmium content on whole soil basis is significantly different. Although this may be a speculation without sufficient supporting evidence, it offers some soil chemical implications that would worth noting in planning soil remediation in this area. Firstly, one should not expect monotonous decrease of the cadmium content with depth in this area because clay rich layers, in which cadmium accumulates, could intervene. Secondly, not only the total cadmium content on whole soil basis but also the clay content of soils should be measured to estimate the depth of soil that has to be rehabilitated.

Yamada (1979) examined the relationship between the cadmium uptake by rice and wheat and the content of $0.1 \mathrm{~mol}^{-1} \mathrm{HCl}-$ soluble cadmium and found that the wheat absorbs much more cadmium than rice and that the cadmium content in the wheat grain exceeds $0.2 \mathrm{mg} \mathrm{kg}^{-1}$ even when the $\mathrm{HCl}$ soluble cadmium content was as low as $1 \mathrm{mg} \mathrm{kg}^{-1}$. Mori and Wada (2002) showed that more than $95 \%$ of the cadmium in soils in this area is 
extractable in $0.1 \mathrm{~mol} \mathrm{~L}^{-1}$ nitric acid. These data suggest that the remediation of topsoil is not necessarily sufficient for growing upland crops including wheat and soybean in this area. The information about the vertical as well as horizontal distribution of cadmium is indispensable for land planning land use and remediation practices. On the basis of the present results, the authors are planning systematic soil survey in this area.

\section{ACKNOWLEDGMENTS}

The authors thank anonymous owner of the land for kind permission of taking soil samples. This study was supported in part by a Grant-in-Aid for Scientific Research from Japanese Society of Promotion of Sciences (\#14350259).

\section{REFERENCES}

Asami, T. 1991 Future problems of heavy metal pollution of Soils. In "Heavy Metal Pollution of Soils" ed. by Japanese Society of Soil Science and Plant Nutrition, Haku-Yu-sha, Tokyo, pp. 113-135

Asami, T. and K. Kato 1977 Comparison of analytical methods for total cadmium, zinc, lead and copper in soils. Jpn. J. Soil Sci. Plant Nutr., 48: 335-336

Darmawan and S. -I. Wada 1999 Kinetics of speciation of $\mathrm{Cu}, \mathrm{Pb}$ and $\mathrm{Zn}$ loaded to soil at low moisture content. Commn. Soil Sci. Plant Anal., 30: 2363-2375

Hai, D. N., Huy, T. Q. and K. Egashira 2002 Mineralogy and clay degradation in grey degraded soils of Viet Nam. Clay Sci. 11: 535-547

Kawamura, K. 1996 Present state and tasks of soil pollution control measures. Environ. Res., 104: 26-36

Mori, Y. anc S. -I. Wada 2002 Cadmium dissolution from cadmium polluted smectitic paddy soil in acid solution. Nendo Kagaku, 41: 196-201

Wada, S. -I. and Y. Umegaki 2001 Major ion and electrical potential distribution in soil under electrokinetic remediation. Environ. Sci. Technol.; 35: 2151-2155

Wolt, J. : 1994 Soil Solution Chemisttry. John Wiley \& Sons, New York

Yamada, K. 1979 Soil pollution by copper mine and zinc refinery works. In. "Analysis of the Mechanism of Soil Pollution", ed. by M. Shibuya, Sangyo-tosho, Tokyo, pp. 1-37

Yoshiike, A. 1979 Soil pollution status and countermeasures. In "Analysis of the Mechanism of Soil Pollution", ed. by M. Shibuya, Sangyo-tosho, Tokyo, pp. 129-160 